\title{
Peningkatan Kesadaran Masyarakat Pesisir Pangandaran dalam Menangani Dampak Sampah di
} Lingkungan Pesisir

\section{Increasing Awareness of Pangandaran Coastal Communities in Handling the Impact of Waste in the Coastal Environment}

\author{
Ahmad Rizal $^{1}$, Izza Mahdiana Apriliani ${ }^{1}$, Rega Permana ${ }^{1}$
}

Korespondensi Penulis:

\section{Ahmad Rizal \\ E-mail: achmad.rizal@unpad.ac.id \\ ${ }^{1}$ Departemen Perikanan, Fakultas Perikanan dan Ilmu Kelautan, Universitas Padjadjaran, Sumedang}

Submitted Jan 26, 2021.

Revised Jan 29, 2021.

Accepted Jan 31, 2021.

\begin{abstract}
Pangandaran, which is one of the popular tourism destinations in West Java Province, has a high potential for pollution. Moreover, its status as a tourist area that brings in tourists both local and international, gave a greater probability of waste disposal. This is a special concern for the government to continue to pay attention to good waste management while maximizing the development of economic potential in Pangandaran Regency. This community service activity aims to increase awareness of the coastal residents of Pangandaran Regency about the impact and dangers of waste in coastal areas. Community service activities are carried out in the form of material exposures and panel discussions. The presentation of the material was held at the Pananjung Village Meeting Hall in September with the target audience of Empowerment of Family Welfare members. The presentation material covers the background conditions of the existing waste problem in Pangandaran, the impact of waste on coastal and marine areas followed by alternative waste management that can be carried out by local women. The results of the activity showed an increase in awareness as seen from the panel discussion session which showed the activeness of the participants in providing questions and answers to the quizzes that had been prepared by the team. Overall, this service activity provides new knowledge for coastal residents to care more about waste management in order to help maintain the cleanliness of the coastal environment.
\end{abstract}

Keywords: coastal area, coastal communities, environmental awareness, environmental impact, waste management

Abstrak

Pangandaran yang merupakan salah satu daerah tujuan pariwisata populer di Provinsi Jawa Barat, memiliki potensi pencemaran tinggi. Terlebih lagi statusnya sebagai daerah wisata yang mendatangkan wisatawan baik dari lokal maupun internasional sehingga probabilitas buangan sampah yang dihasilkan menjadi lebih besar. Hal ini menjadi perhatian khusus bagi pemerintah untuk tetap memperhatikan pengelolaan sampah yang baik disamping memaksimalkan pengembangan potensi ekonomi di Kabupaten Pangandaran. Kegiatan pengabdian kepada masyarakat kali ini bertujuan untuk meningkatkan kesadaran warga pesisir Kabupaten Pangandaran akan dampak dan bahaya sampah di wilayah pesisir. Kegiatan ini dilakukan dalam bentuk paparan materi dan diskusi panel di Gedung Balai Desa Pananjung pada bulan September dengan khalayak sasaran ibu-ibu anggota Pemberdayaan Kesejahteraan Keluarga. Materi pemaparan meliputi latar belakang kondisi existing permasalahan sampah yang ada di Pangandaran, dampak sampah terhadap wilayah pesisir dan laut diikuti dengan alternatif pengelolaan sampah yang dapat dilakukan oleh ibu-ibu setempat. Hasil kegiatan menunjukan adanya peningkatan kesadaran, dilihat dari sesi panel diskusi yang menunjukan keaktifan para peserta dalam memberikan pertanyaan dan menjawab kuis yang telah disiapkan oleh tim. Secara keseluruhan kegiatan pengabdian ini memberikan pengetahuan dan wawasan bagi warga pesisir agar lebih peduli terhadap pengelolaan sampah dalam rangka menjaga kebersihan lingkungan pesisir.

Kata Kunci: dampak lingkungan, kesadaran lingkungan, masyarakat pesisir, pengelolaan sampah, wilayah pesisir 


\section{Pendahuluan}

Indonesia merupakan negara dengan tingkat produksi sampah tertinggi kedua di dunia setelah China dengan jumlah timbunan sampah mencapai 67,8 juta ton di pertengahan tahun 2020 (Juniartini, 2020; IDN Times, 2020). Sebagian dari timbunan sampah tersebut merupakan sampah domestik yang tersusun dari berbagai jenis sampah termasuk diantaranya plastik. Menurut laporan Lembaga Ilmu Pengetahuan Indonesia (LIPI), sebanyak 400 ribu ton sampah plastik masuk ke lingkungan pesisir dan laut Indonesia setiap tahunnya (Tempo, 2018). Secara global jumlah sampah plastik yang memasuki wilayah laut bahkan mencapai 8 juta ton setiap tahun (McArthur, 2017).

Sampah plastik yang masuk ke wilayah laut dan pesisir ini selain menimbulkan masalah lingkungan, akan membahayakan kehidupan organisme di dalamnya sehingga akan menyebabkan terjadinya ketidakseimbangan ekosistem. Plastik akan terurai dalam waktu yang sangat lama dan dalam prosesnya plastik akan terfragmentasi ke dalam ukuran yang lebih kecil menjadi mikroplastik. Mikroplastik ini akan memberikan efek negatif terhadap berbagai bentuk kehidupan di laut dan juga telah banyak dilaporkan merugikan secara fisiologis bahkan bersifat lethal (Guzzetti et al., 2018; LopezRojo et al., 2020). Oleh karena itu perlu adanya upaya pengelolaan sampah yang baik agar dampaknya dapat dihindari.

Wilayah pesisir merupakan wilayah yang berpotensi mengalami dampak pencemaran tinggi karena sebagian besar aktivitas manusia berada di wilayah ini (Crossett et al., 2004). Provinsi Jawa Barat adalah Provinsi dengan jumlah penduduk terpadat di Indonesia, hampir $25 \%$ penduduk Indonesia berdomisili di Provinsi ini. Wilayah pesisir di Provinsi Jawa Barat terbagi menjadi dua yaitu pesisir utara dan pesisir selatan. Daerah Pesisir Selatan Jawa Barat banyak dijadikan destinasi wisata karena keindahan alamnya, salah satu diantaranya adalah kawasan wisata pantai Kabupaten Pangandaran. Sebagai wilayah di Jawa Barat yang menjadi icon pariwisata bahari, Pangandaran memegang peranan strategis dalam pengembangan kewilayahan provinsi Jawa Barat. Statusnya sebagai daerah wisata yang mendatangkan wisatawan baik dari lokal maupun internasional menyebabkan probabilitas buangan sampah yang dihasilkan menjadi lebih besar. Dikutip dari pemberitaan di media, saat musim liburan tiba jumlah sampah di
Pangandaran khususnya di daerah pantai wisata bisa mencapai $3000 \mathrm{~m}^{3}$ (Kompas, 2019). Awal tahun 2020 ini, menurut laporan Dinas Lingkungan Hidup dan Kebersihan Kabupaten Pangandaran peningkatan jumlah sampah di Pantai Pangandaran melonjak drastis hingga mencapai empat kali lipat dari biasanya (Republika, 2020).

Warga pesisir memegang peranan penting dalam membantu menjaga kebersihan lingkungan pesisir dari pencemaran sampah. Peran strategis ini menjadikan pengetahuan dan informasi mengenai bahaya dampak sampah di lingkungan pesisir dan laut sangat penting untuk dipahami oleh warga pesisir. Pemahaman yang dalam akan bahaya dan pentingnya menjaga lingkungan akan membantu pembentukan pola pikir yang disiplin dan tertib dalam pengelolaan sampah di ruang lingkup terkecil yaitu rumah tangga. Kegiatan pengabdian kepada masyarakat ini bertujuan untuk meningkatkan kesadaran warga pesisir Kabupaten Pangandaran akan dampak dan bahaya sampah di wilayah pesisir. Khalayak sasaran ditujukan bagi ibu rumah tangga anggota Pemberdayaan Kesejahteraan Keluarga (PKK) di sekitar wilayah Pangandaran. Pemilihan khalayak sasaran tersebut dilakukan karena ibu rumah tangga merupakan kelompok masyarakat yang akan langsung bersentuhan dengan aktivitas sehari-hari yang berpotensi menghasilkan sampah domestik rumah tangga, terutama plastik. Selain itu kelompok PKKdinilai aktif dalam kegiatan bermasyarakat sehingga diharapkan akan memiliki dampak perubahan kesadaran yang lebih besar bagi lingkungan sekitarnya (Shalfiah, 2017).

\section{Materi dan Metode Pelaksanaan}

\section{Waktu dan tempat pelaksanaan}

Kegiatan pengabdian kepada masyarakat dilakukan dalam tiga tahapan yang meliputi tahap persiapan, tahap pelaksanaan dan tahap evaluasi. Tahap persiapan dilakukan pada bulan agustus 2020 dengan melakukan survei inisiasi dan sosialisi dengan pemerintah setempat, termasuk dinas kelautan perikanan dan ketahanan pangan kabupaten pangandaran serta pemerintah setempat. Tahap pelaksanaan kegiatan yang berupa pemaparan materi utama dilakukan pada tanggal 16 September 2020 bertempat di Balai Desa Pananjung Kecamatan Pangandaran Kabupaten Pangandaran. Evaluasi dilakukan setelah rangkaian kegiatan pemaparan materi selesai dengan format tanya jawab (questions and answers). 


\section{Khalayak Sasaran}

Lokasi yang akan dijadikan sebagai tempat kegiatan adalah Desa Pananjung Kecamatan Pangandaran, Kabupaten Pangandaran. Tempat ini dipilih atas rekomendasi dari Dinas Perikanan setempat yang merupakan aktivitas pesisir yang padat. Adapun kelompok sasaran dari kegiatan ini adalah ibu rumah tangga anggota PKK dari Desa Pananjung yang aktif dalam sosialisasi kegiatan bermasyarakat. Kelompok PKK ini dipilih karena dianggap sebagai agent of change dalam kegiatan lingkungan di wilayah pesisir Pangandaran.

\section{Tahap Persiapan}

Tahap pertama merupakan tahap persiapan kegiatan secara keseluruhan yang meliputi sosialisasi dan inisiasi kegiatan ke dinas dan pemerintah setempat, pemilihan khalayak sasaran kegiatan serta pemilihan dan persiapan tempat pelaksanaan kegiatan. Secara keseluruhan tahap persiapan ini dilakukan dengan metode survei lapangan dengan langsung mendatangi lokasi kegiatan. Sosialisasi dan inisiasi dilakukan dengan mendatangi Kesbangpol Pangandaran dan Dinas Kelautan Perikanan dan Ketahanan Pangan Kabupaten Pangandaran untuk menyampaikan rencana kegiatan sekaligus diskusi mengenai pemilihan khalayak sasaran yang sesuai dengan tema dan tujuan kegiatan ini. Setelah diskusi dan direkomendasikan untuk melakukan kegiatan di desa pananjung, audiensi dengan pihak desa dilakukan sekaligus pemilihan dan persiapan tempat yang sesuai untuk melakukan kegiatan. Tempat yang dipilih harus sesuai dan memenuhi persyaratan untuk penyelenggaraan forum dengan minimal kapasitas 150 orang. Hal ini berkaitan dengan penerapan protokol kesehatan untuk mencegah penularan virus Covid-19. Selanjutnya untuk memenuhi aturan protokol kesehatan, jumlah peserta maksimum yang ditetapkan sebanyak $30 \%$ dari total kapasitas ruangan atau 50 orang.

\section{Tahap Pelaksanaan}

Tahap pelaksanaan kegiatan dilaksanakan dengan menggunakan metode ceramah dan diskusi. Dalam mempercepat proses pencapaian tujuan dengan pendidikan dan pelatihan harus dapat menyampaikan pesan perubahan secara efektif dan efisien. Untuk itu dibutuhkan proses komunikasi dua arah dengan menanamkan motivasi kepada ibu rumah tangga anggota PKK untuk meningkatkan kesadaran mengenai dampak lingkungan dan pengelolaan sampah di pesisir.

Khalayak sasaran akan diberikan pengetahuan dengan cara penyuluhan tentang masyarakat mengetahui bahaya dan dampak sampah plastik serta teknik pengelolaan sampah plastik yang baik bagi masyarakat pesisir. Kegiatan ini merupakan kegiatan belajar sambil menekankan pemahaman dan kesadaran. Hasil dari kegiatan ini diharapkan membawa perubahan dalam hal pengetahuan (knowledge), cara berfikir (thinking), kecakapan (skill) dan sikap. Sehingga capaian yang diharapkan dari penyuluhan terpenuhi.

\section{Tahap Evaluasi}

Evaluasi dilakukan dengan metode tanya jawab (questions and answers) setelah pemaparan materi dan sesi diskusi selesai. Tim menyiapkan beberapa pertanyaan mengenai isi materi secara umum kemudian para peserta menjawab pertanyaan. Partisipasi peserta dan ketepatan pemahaman konsep materi peserta menjadi poin utama dalam tahapan evaluasi ini.

\section{Hasil dan Pembahasan}

\section{Tahap Persiapan}

Dalam proses pelaksanaan kegiatan, tahap persiapan merupakan tahap yang cukup penting. Persiapan kegiatan dengan melakukan inisiasi kepada Kesbangpol Pangandaran, Dinas Kelautan Perikanan dan Ketahanan Pangan Kabupaten Pangandaran bahwa kegiatan yang direncanakan dilakukan di Kecamatan Pangandaran. Tim beraudensi dengan pihak Desa Pananjung yang ditunjuk sebagai tempat pelaksanaan serta melakukan survei lokasi untuk pelaksanaan kegiatan ini (Gambar 1). Hasil audensi sangat positif, pihak Desa mendukung dan mengijinkan untuk dilakukannya kegiatan ini. Salah satu bentuk dukungan yang diberikan oleh pihak Desa yaitu dengan diperbolehkannya balai desa sebagai tempat pertemuan untuk penyampaian materi dalam kegiatan ini. Selain itu, Desa Pananjung juga membantu dalam teknis pengumpulan khalayak sasaran yaitu ibu-ibu PKK di wilayah Pesisir Kabupaten Pangandaran.

Pelaksanaan kegiatan ini bertepatan dengan masa pandemi Covid-19 sehingga kami tetap dihimbau untuk melaksanakan kegiatan dalam koridor protokol kesehatan (Gambar 2). Maka dari itu Pelaksanaan dilaksanakan dalam ruangan terbuka 
dengan kapasitas besar sehingga dapat menampung ibu-ibu PKK dengan kaidah physical distancing.
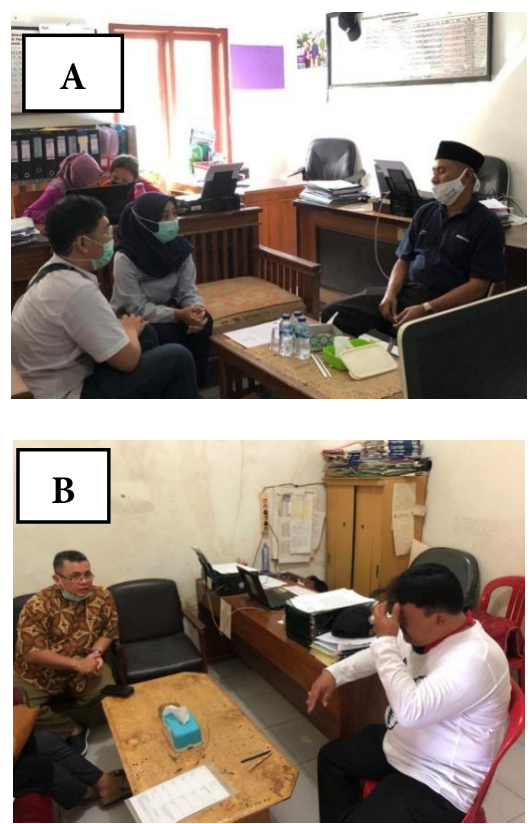

Gambar 1. Inisiasi dan Sosialisasi Kegiatan

Pengabdian Kepada Masyarakat di A) Dinas Kelautan Perikanan dan Ketahanan Pangan dan B) Pihak Desa Pananjung

Hal ini semua telah memperoleh ijin dan kesepakatan oleh pihak-pihak terkait sehingga kegiatan diharapkan tetap dilaksanakan dengan lancar. Balai Desa Pananjung yang merupakan lokasi pelaksanaan kegiatan merupakan ruang dengan kapasitas besar hingga mencapai 150 orang. Dengan demikian peserta yang diundang dibatasi hingga 50 orang, sesuai aturan protokol kesehatan.
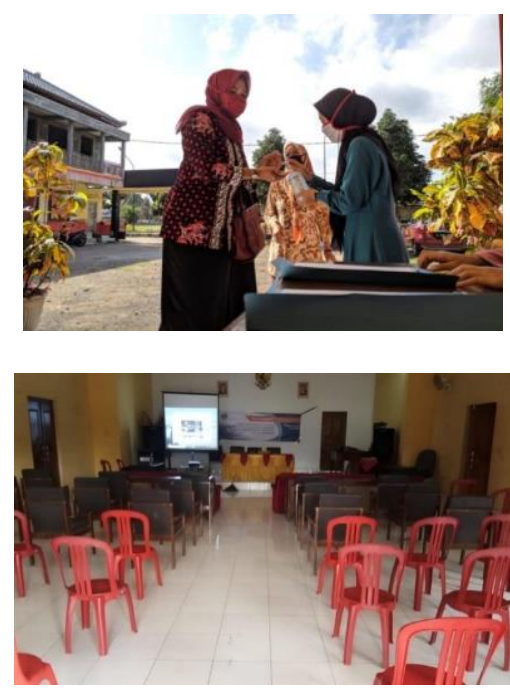

Gambar 2. Penerapan Aturan Protokol Kesehatan dan kaidah Physical Distancing

\section{Tahap Pelaksanaan dan Evaluasi}

Pelaksanaan kegiatan dilakukan di Balai Desa Pananjung Kecamatan Pangandaran pada tanggal 16 September 2020. untuk mentaati aturan protokol kesehatan, ruangan diatur supaya mengikuti kaidah physical distancing dan disediakan masker serta hand sanitizer di meja registrasi. Waktu yang dialokasikan berkisar 2 hingga 3 jam yang meliputi sambutan dari pihak Universitas Padjadjaran dan Kantor Desa diikuti dengan sesi pemaparan dan diskusi serta evaluasi tanya jawab peserta. Kurang lebih 43 peserta mengahadiri kegiatan dengan 37 peserta khalayak sasaran yaitu ibu rumah tangga anggota PKK dan sisanya merupakan perwakilan desa dan perwakilan Badan Pembangunan Daerah (BPD) Desa Pananjung. Ibu rumah tangga anggota PKK Desa Pananjung tersebar di tiga dusun yang berbeda yaitu Dusun Karang Sari, Dusun Karang Salam dan Dusun Bojong Jati. Secara umum sebaran target peserta yang hadir berdasarkan asal dusun dapat dilihat pada gambar 3. mayoritas ibu rumah tangga anggota PKK yang hadir berdomisili di Dusun Karang Sari.

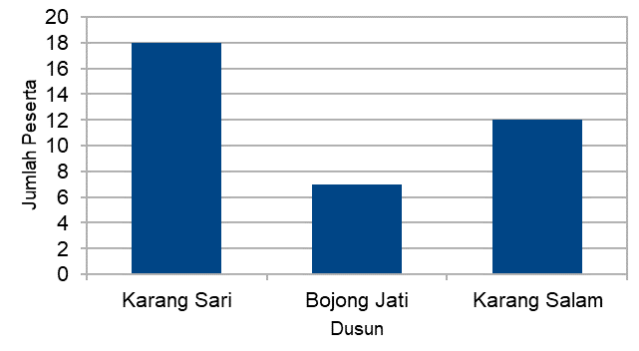

Gambar 3. Sebaran Peserta Kegiatan Berdasarkan Domisili

Materi yang dipaparkan meliputi jenis dan klasifikasi sampah yang dihasilkan di ruang lingkup rumah tangga dilengkapi dengan kondisi existing permasalahan sampah di Kabupaten Pangandaran secara umum. Kemudian dilanjutkan dengan pemaparan bahaya dan dampak sampah terhadap lingkungan pesisir dan bagaimana dampaknya dapat dirasakan juga oleh warga setempat. Pemutaran beberapa video dokumenter terkait bahaya dampak sampah di pesisir memberikan gambaran mengenai kondisi dan status pencemaran sampah di wilayah pesisir saat ini. Paparan juga dilengkapi dengan alternatif pengelolaan sampah yang dapat dilakukan oleh warga seperti composting dan daur ulang hingga menjadi produk bernilai ekonomi. 
Selama berlangsungnya kegiatan, presepsi peserta terhadap materi yang disampaikan cukup baik. Hal ini terlihat dari adanya interaksi positif pada saat paparan materi antara presenter dan peserta. Saat sesi diskusi dilakukan, secara aktif peserta menyampaikan permasalahan dan kendala yang dialami dalam pengelolaan sampah (Gambar 4). Kendala umum yang sering dialami oleh sebagian peserta adalah penggunaan plastik yang tidak dapat dihindari sehingga produksinya juga sulit untuk ditekan. Hal ini dapat diatasi dengan proses recycle atau daur ulang sampah plastik menjadi produk fungsional bernilai ekonomi seperti vas bunga dan hiasan. Tata cara daur ulang juga dipresentasikan melalui video tutorial yang aplikatif.
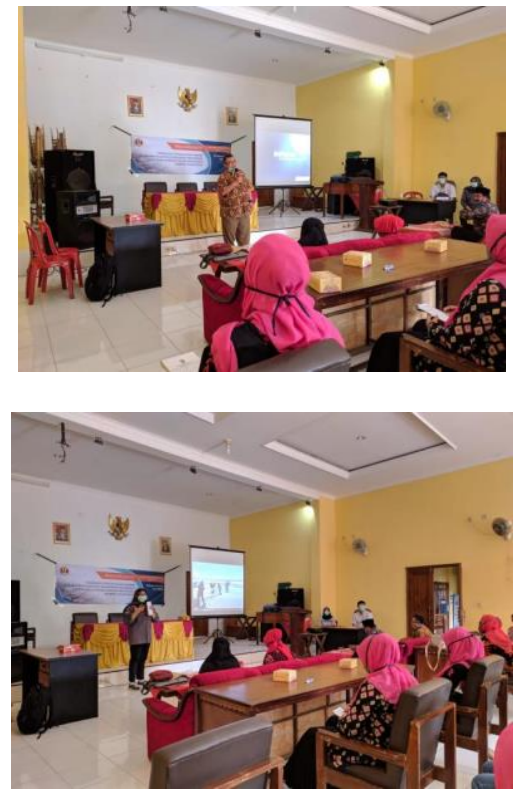

Gambar 4. Pelaksanaan Kegiatan Pengabdian Kepada Masyarakat

\section{Kesimpulan}

Secara Kegiatan Pengabdian Kepada Masyarakat ini telah berhasil diselenggarakan dengan tetap memperhatikan aturan protokol kesehatan untuk mencegah penyebaran Covid-19. Khalayak sasaran kegiatan yaitu ibu rumah tangga anggota PKK yang hadir sebagai peserta didominasi oleh Dusun Karang Sari diikuti Dusun Karang Salam dan Dusun Bojong Jati. Materi pemaparan dapat tersampaikan dengan baik dan dipahami oleh peserta yang dilihat dari keaktifan saat sesi diskusi dan evaluasi.

\section{Ucapan Terimakasih}

Pengabdian kepada masyarakat ini merupakan rangkaian kegiatan integrasi dari riset percepatan lektor kepala (RPLK) yang didanai oleh Hibah Internal Universitas Padjadjaran (HIU). Penulis mengucapkan terima kasih kepada semua pihak yang terlibat dalam pelaksanaan kegiatan pengabdian kepada masyarakat ini.

\section{Daftar Pustaka}

Crossett, K. M., Culliton, T. J., Wiley, P. C., \& Goodspeed, T. R. (2004). Population trends along the coastal United States: 1980-2008 (Vol. 55). US Department of Commerce, National Oceanic and Atmospheric Administration, National Ocean Service, Management and Budget Office, Special Projects.

Guzzetti, E., Sureda, A., Tejada, S., \& Faggio, C. (2018). Microplastic in marine organism: Environmental and toxicological effects. Environmental toxicology and pharmacology, 64, 164-171.

IDN Times. 2020. KLHK: Jumlah Sampah Nasional 2020 Mencapai 67,8 Juta Ton. [internet] [dapat diakses di

https://www.idntimes.com/news/indonesia/aldzah -fatimah-aditya/klhk-jumlah-sampah-nasional2020-mencapai-678-juta-ton/3]

Juniartini NLP. (2020). Pengelolaan Sampah Dari Lingkup Terkecil dan Pemberdayaan Masyarakat sebagai Bentuk Tindakan Peduli Lingkungan. Jurnal Bali Membangun Bali, 1(1), 27-40.

Kompas. 2019. Sampah di Pangandarann 3000 meter kubik saat libur Pemda diminta Bertindak. [internet] [dapat diakses di https://regional.kompas.com/read/2019/06/28/172 62351/sampah-di-pangandaran-3000-meterkubik-saat-libur-pemda-dimintabertindak?page $=$ all]

López-Rojo, N., Pérez, J., Alonso, A., Correa-Araneda, F., \& Boyero, L. (2020). Microplastics have lethal and sublethal effects on stream invertebrates and affect stream ecosystem functioning. Environmental Pollution, 259, 113898.

MacArthur, E. (2017). Beyond plastic waste. Science. $358,843-843$.

Republika. 2020.Volume Sampah di Pangandaran Meningkat Drastis. [internet] [dapat diakses di https://republika.co.id/berita/daerah/jawabarat/20/01/02/q3h5qs368-volume-sampah-dipangandaran-meningkat-drastis]

Shalfiah, R. (2017). Peran pemberdayaan dan 
Rizal et al (2021) FJCS 02(1): $24-29$

kesejahteraan keluarga (PKK) dalam mendukung program-program pemerintah kota bontang. Jurnal Universitas Mulawarman, 1(3), 975-984.

Tempo. 2018. LIPI: 400 Ribu Ton Sampah Plastik Masuk ke Laut Tiap Tahun. [internet] [dapat diakses di https://tekno.tempo.co/read/1155151/lipi-400-

ribu-ton-sampah-plastik-masuk-ke-laut-tiap-tahun] 